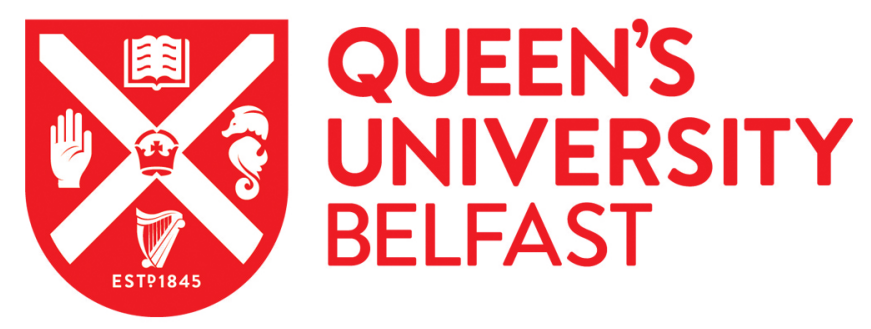

\title{
An Exceptional Case of Healed Vertebral Wound with Trapped Bronze Arrowhead: Analysis of a 7th-6th c. bc Individual from Central
} Kazakhstan

Tur, S. S., Svyatko, S. V., Beisenov, A. Z., \& Tishkin, A. A. (2016). An Exceptional Case of Healed Vertebral Wound with Trapped Bronze Arrowhead: Analysis of a 7th-6th c. bc Individual from Central Kazakhstan. International Journal of Osteoarchaeology, 26(4), 740-746. https://doi.org/10.1002/oa.2470

Published in:

International Journal of Osteoarchaeology

Document Version:

Peer reviewed version

Queen's University Belfast - Research Portal:

Link to publication record in Queen's University Belfast Research Portal

Publisher rights

Copyright 2016 Wiley. This work is made available online in accordance with the publisher's policies. Please refer to any applicable terms of use of the publisher.

\section{General rights}

Copyright for the publications made accessible via the Queen's University Belfast Research Portal is retained by the author(s) and / or other copyright owners and it is a condition of accessing these publications that users recognise and abide by the legal requirements associated with these rights.

Take down policy

The Research Portal is Queen's institutional repository that provides access to Queen's research output. Every effort has been made to ensure that content in the Research Portal does not infringe any person's rights, or applicable UK laws. If you discover content in the

Research Portal that you believe breaches copyright or violates any law, please contact openaccess@qub.ac.uk. 
Title: An Exceptional Case of Healed Vertebral Wound with Trapped Bronze Arrowhead: Analysis of a $7^{\text {th }}-6^{\text {th }}$ c. BC Individual from Central Kazakhstan Running title: A Case of Healed Vertebral Wound with Trapped Bronze Arrowhead

Authors: Svetlana S. Tur ${ }^{\mathrm{a}}$, Svetlana V. Svyatko ${ }^{\mathrm{b} *}$, Arman Z. Beisenov $^{\mathrm{c}}$, Aleksei A. Tishkin ${ }^{\mathrm{d}}$

a. Museum of Archaeology and Ethnography of Altai, Altai State University, Leninskiy prospect, 61, Barnaul 656049, Russian Federation

b. ${ }^{14}$ CHRONO Centre for Climate, the Environment, and Chronology; Queen's University of Belfast, Belfast BT7 1NN, Northern Ireland, UK

c. Institute of Archaeology n.a. A. Kh. Margulan, 44 Avenue Dostyk, st. Shevchenko 28, Almaty 050010, Kazakhstan

d. Department of Archaeology, Ethnography and Museology; Altai State University, Leninskiy prospect, 61, Barnaul 656049, Russian Federation

*Correspondence to: Dr. Svetlana Svyatko, ${ }^{14}$ CHRONO Centre for Climate, the Environment, and Chronology; Queen's University of Belfast, Belfast BT7 1NN, Northern Ireland, UK.

Tel.: +44 (0)2890973974

E-mail: s.svyatko@qub.ac.uk

\section{Abstract}

Projectile injury caused by an arrow shot is a common skeletal marker of interpersonal violence in archaeological populations. The injuries of the spine were usually fatal. Only few reports on healing of the vertebra pierced by flint arrowpoint can be found in bioarchaeological literature. This paper presents an exceptional case of a healed trapped bronze arrowhead wound in the spine of a 7th - 6th c. BC elite nomad from Central Kazakhstan. Computed radiography and tomography as well non-destructive X-ray fluorescence spectrometry provide detailed information about the context and mechanism of the injury.

Key words: arrowhead, arrow wound, spine, Central Kazakhstan, Early Iron Age

\section{Introduction}

Projectile injury caused by an arrow shot is a common skeletal marker of interpersonal violence in archaeological populations around the world (e.g. Lambert, 1997; Guilaine, Zammit, 2005). Arrowheads embedded in the human bones are generally very difficult to extract (Bill, 1862). If the vital organs were not damaged, the foreign object lodged in the bone usually gets obliterated, indicating total recovery (Wilson, 1901). The injuries of the spine were lethal in most cases (Rokhlin, 1965; Atkinson, Evans, 1978; Polos'mak, Molodin, 1981; Reuer,1984; Stork, Wahl, 1988; Etxeberria et al., 1991; Campillo et al., 1993; Armendariz et al., 1994; Schutkowski et al., 1996; Lambert, 1997; Guilaine, Zammit, 2005; Jurmain et al., 2009; Meyer et al., 2009; Silva, Marques, 2010; Vegas et al., 2012; and others). Only few reports on healing of the vertebra pierced by flint arrowpoint can be found in bioarchaeological literature (Wilson, 1901; Jurmain, 2001; Jurmain et al., 2009; Vegas et al., 2012). This paper presents an exceptional case of a healed trapped bronze arrowhead wound in the spine. 
The anthropological material comes from kurgan 1 of the Koitas cemetery in Central Kazakhstan excavated in 2011 (Figure 1). The kurgan belonged to the Early Saka nomadic aristocracy and was completely plundered in ancient times. Only few disarticulated human bones (a vertebra, ribs, and fibulae) have been recovered from the filling of the burial pit (Figure 1S). They have been AMS radiocarbon dated to the 791-536 cal BC (UBA-23664; Beisenov et al., in prep.).

Only the body of the vertebra, yet exposing sagittal cut by a sharp tool (добавьте, что случайно поврежден при раскопках), was available for the morphological analysis (Figure 2a). Two antemortem injuries can be observed macroscopically - the vertebral body was lodged by an arrowpoint, and one rib has a well-defined callus of new bone, which usually forms around the fracture. Computed radiography $(\mathrm{CR})$ and computed tomography $(\mathrm{CT})$ were used for better visualization of the arrowhead and detailed examination of the injury.

Siding and sequencing of the isolated ribs being essential for determination of the exact location of the chest trauma, and for sex and age estimation of the individual was carried out according the morphological criteria by Mann (1993), Dudar (1993), Jellema et al. (1993) and certain metric dimensions by Hoppa \& Saunders (1998), Owers \& Pastor (2005), Cirillo \& Henneberg (2012).

Sex and age at death of the individual were determinated from the sternal extremity of the fourth rib (Işcan et al., 1984; Işcan, 1985). The estimation of the stature of the individual was based on the length of fibula (Sjovold, 1990).

In order to evaluate the risk of metal intoxication of the body, chemical composition of the arrowhead was determined by non-destructive X-ray fluorescence (XRF) spectrometry applying the Innov-X Sistems portable analyzer. Three samples were measured from the arrowhead - two in the pure metal and one in the corrosion crust.

\section{Results}

\section{Gross visual examination}

It has been determined that the human remains belonged to a male of 25-45 years old, ca. 174 $\mathrm{cm}$ tall.

The majority of the ribs have been preserved, excluding right $11^{\text {th }}$ and $12^{\text {th }}$ and left $6^{\text {th }}$ and $10^{\text {th }}$ ribs (Figure S2). The $4^{\text {th }}$ right rib demonstrates an antemortem fracture.

Obviously, the vertebra shows an anatomical transition between the thoracic and lumbar patterns. The size and shape of the body are similar to those of the lumbar vertebrae. However the body bears a single large costal facet on each side, extending on to the part of the pedicle (Figure 2a). As such, the vertebra can be identified as T11 or T12. The two corresponding ribs available make it possible to determine more precisely the position of the vertebra. The left articular facet on the body of the vertebra is congruent with that of the $11^{\text {th }}$ rib head, but not of the $12^{\text {th }}$ rib, which suggests that the considered element is T11.

Schmorl's nodes are located in both cranial and caudal vertebral endplates. The vertebra also exhibits slight horizontal lipping on the superior and inferior margins and a large osteophyte along the left anterolateral aspect, which has a characteristic shape of a «bird's beak», with its free end directed to the nearest intervertebral space (Figure 2a).

On the left side of the vertebral body, near its lower edge and under the articular facet, there is a rounded deep cavity (6-7 $\mathrm{mm}$ in diameter) with smooth margins of remodeled bone and an end (presumably tip) of the bronze arrowpoint inside. The other end of the arrowpoint is visible in the deepening on the right side of the vertebral body near its upper edge and immediately anterior to the articular facet. It is almost entirely covered with a new bony formation (Figure 3 ). From the postmortem sagittal cut of the vertebral body it also appears that the arrowhead is walled off from the cancellous bone by a thin solid bony layer (Figure $3 \mathrm{a}$ ). 


\section{Computed Radiography and Tomography}

The CR confirmed that the arrowhead pierced the vertebral body from right to left and from above (approx. at $21^{\circ}$ angle), close to its dorsal surface. Clearly, it consists of a warhead, possibly damaged, and a tang. No osteolytic lesions related to the object are detected from the radiographs. The thin sclerotic rim immediately adjacent to the arrowhead is badly visible also (Figure 2d, e).

CT scans demonstrate that the warhead is triangular in cross-section with its edges rolling in the narrow blades, and the tang, relatively wide and circular near the warhead, gradually tapers and flatters towards its free end (Figure 6). The arrowhead has the total length of $56 \mathrm{~mm}$ and the maximum diameter of $10 \mathrm{~mm}$. The CT images further show that the very point of the warhead is broken and the outer layer of the warhead flakes off in some places (Figure 4a). Graphycal reconstruction of the arrowhead was made based on the CT scans (Figure 4b).

Archaeologically, the arrowhead is dated to the second half of $7^{\text {th }}-$ first half of $6^{\text {th }} \mathrm{c}$. BC (Čugunov et al., 2010).

\section{$X$-ray fluorescence spectrometry}

The results of XRF analysis indicate that the arrowhead is made of copper $(\mathrm{Cu})$ alloy with high tin $(\mathrm{Sn})$ content; lead $(\mathrm{Pb})$ and iron $(\mathrm{Fe})$, being impurities, constitute in average 0.12 and $0.23 \mathrm{wt} \%$ respectively (Table 1 ); no presence of other elements has been detected. The outer corroded layer consists of pure copper $(99.85 \%)$ with traces of $\mathrm{Fe}(0.15 \%)$.

\section{Discussion}

The penetrating and destructive effect of a projectile depends primarily on its velocity, weight, and design. The arrowhead lodged in the thoracic vertebra of the individual from the elite kurgan of the Koitas cemetery belongs to a military form - it is made of bronze with high level of tin, which is hard and can produce very sharp blades, and has widening of anterior part of the tang, increasing the kinetic energy and, consequently, the penetration power of an arrow.

Removing arrowheads was often a difficult task, partly because of the construction of the arrows. The tanged arrowhead fit usually into a slot at the end of the shaft and was tied with narrow animal tendons and sinews. When the arrow penetrated the body, the tendon got wet from its contact with blood and other bodily fluids and was lengthened, as a result of which the arrowhead would become loosened and readily detached. It was left within the victim's body if the shaft of the arrow is pulled out (Bill, 1862).

As CT scans have shown, the warhead was damaged. It was probably broken by the contact with the bone at the moment of an impact. Although high-tin alloy can produce very sharp blades for cutting the soft tissues, the downside is that it tends to be more brittle at the hit in hard tissues. Mechanical damage of the warhead appears to have accelerated the corrosion of metal, which usually occurs in vivo (Jacobs et al., 1998).

Arrow wounds to the thoracolumbar spine are at risk for life-threatening damaging the heart, lungs, major blood vessels and bowel. They were usually fatal due to immediate massive hemorrhage or subsequent peritonitis. The incidence of septic complications was significantly higher in the lumbar spine than in thoracic one. The pathway of an arrow within a body is important - if a projectile perforates hollow viscus before entering the spine, there is a higher risk of developing secondary spinal infections (Romanick et al., 1985; Isiklar \& Lindsey, 1998; de Barros Filho et al., 2014). Besides, bacteria could be further carried into the wound by contaminated arrowhead itself. In cases of arrow wounds penetrating the chest if the victim survives the period of hemorrhage and the arrowhead has not lodged in the lung tissue, the consecutive inflammation is usually trifling (Bill, 1882). 
Expectedly, the arrowhead penetrating the vertebra induced an inflammatory reaction that led to a resorption cavity associated with peripheral sclerotic formation (osteomyelitis). However, the cavity surrounding the foreign body can only be observed visually on the sagittal cut of the vertebra. Both $\mathrm{CR}$ and $\mathrm{CT}$ failed to identify the bone injury as cavitation. Unfortunately, at presence of metallic foreign bodies, CT images are often obscured by artifacts and conceal details (Boas \& Fleischmann, 2012). The entrance hole on the right side of the vertebra was affected by the sclerotic healing process, whereas the opening on the opposite side appeared as a drainage sinus. The inflammatory reaction may have occured in response not only to mechanical irritation and bacterial contamination of the arrowhead but also to its corrosion product (Roy et al., 2012).

Metal projectile retained within the body can lead to both systemic and local intoxication of tissues. The location of the projectile is crucial. Animal studies have demonstrated that copper can cause a severe local necrosis of both brain and spinal cord tissue but only if located intradurally (Cushid \& Kopeloff, 1968; Tindel et al., 2001). A number of cases of systemic lead poisoning, also known as plumbism, have been reported in the medical literature for patients with retained bullets in the spine (Machle, 1940; Linden et al., 1982). Bullet in close proximity to facet joints or the intervertebral disc is more likely to develop this complication (Machle, 1940; Grogan \& Bucholz, 1981). However, low lead concentration in the copper alloy of the analysed arrowhead, as well as its location in the vertebral body without contact with the spinal cord, seem to have excluded the risk of metal intoxication in the individual from Koitas.

Besides the arrow wound of the spine the analysed individual had also a well-healed fracture of the $4^{\text {th }}$ right rib. These traumas could have been suffered at the same or different times. Rib fractures may results from accidents during daily activities or interpersonal aggression (Lovell, 1997).

\section{Conclusion}

\section{Acknowledgments}

This work has been supported by the Ministry of Education and Science of the Russian Federation grant 14.Z50.31.0010 (project "The Earliest Colonization of Siberia: Formation and Dynamics of the North Asian Cultures"). We would like to express our thankfulness to Dr. G.G. Kravchenko (Tomsk State University) for providing us with map, Dr. S.A. Pechenin (City Hospital № 1, Barnaul) for CR and CT images, and Dr. A.L. Kungurov (Altai State University) for the graphic reconstruction of the arrowhead.

\section{Supporting Information}

Additional supporting information may be found in the online version of this article at the publisher's web site.

Figure 1S. Plan and cross-section of the grave, kurgan 1 of the Koitas cemetery.

Figure 2S. Ribs from the filling of the grave (Koitas cemetery kurgan 1), placed in anatomical order; dorsal view.

\section{References}

Armendariz J, Irigarai S, Etxeberria F. 1994. New evidence of prehistoric arrow wounds in the Iberian Peninsula. International Journal of Osteoarchaeology 4(3): 215-222. DOI: 10.1002/oa.1390040306

Atkinson RJC, Evans JG. 1978. Recent excavations at Stonehenge. Antiquity 52:235-236. 
Bill JH. 1862. Notes on arrow wounds. American Journal of the Medical Sciences 40(88): 365387.

Bill JH. 1882. Sabre and bayonet wounds; arrow wounds. In The international encyclopedia of surgery, Ashhurst J (ed.). W.Wood \& Company: New York; 101-117.

Boas FE, Fleischmann D. 2012. CT artifacts: Causes and reduction techniques. Imaging in Medicine 4(2): 229-240.

Campillo D, Mercadal O, Blanch R-M. 1993. A mortal wound caused by a flint arrowhead in individual MF-18 of the neolithic period exhumed at Sant Quirze del Valles. International Journal of Osteoarcbaeology 3: 145-150. DOI: 10.1002/oa.1390030212

Cirillo J, Henneberg M. 2012. Sequencing human ribs into anatomical order by quantitative multivariate methods. Homo 63: 182-201. DOI: 10.1016/j.jchb.2012.04.001

Čugunov KV, Parzinger H, Nagler A. 2010. Der skythenzeitliche Fürstenkurgan Aržan 2 in Tuva. Verlag Philipp von Zabern: Mainz.

Cushid J, Kopeloff L. 1968. Epileptogenic effects of metal powder implants in the motor cortex in monkeys. International Journal of Neuropsychiatry 3: 24-28.

de Barros Filho TE, Cristante AF, Marcon RM, Ono A, Bilhar R. 2014. Gunshot injuries in the spine. Spinal Cord 52(7):504-510. DOI: $10.1038 / \mathrm{sc} .2014 .56$

Dudar JC. 1993. Identification of rib number and assessment of intercostal variation at the sternal rib end. Journal of Forensic Sciences 38: 788-797.

Grogan DP, Bucholz RW. 1981. Acute lead intoxication from a bullet in an intervertebral disc space. A case report. Journal of Bone and Joint Surgery 63a(7): 1180-1182.

Guilaine J, Zammit J. 2005 The origins of war: violence in prehistory. Blackwell Publishing: Oxford.

Hoppa RD, Saunders S. 1998. Two quantitative methods of rib seriation in human skeletal remains. Journal of Forensic Sciences 43: 185-191.

Isiklar ZU, Lindsey RW. 1998. Gunshot wounds to the spine. Injury 29a(1): 7-12.

İscan MY, Loth SR, Wright RK. 1984. Metamorphosis at the sternal rib end: A new method to estimate age at death in white males. American Journal of Physical Anthropology 65(2): 147156.

Işcan MY. 1985. Osteometric analysis of sexual dimorphism in the sternal end of the rib. Journal of Forensic Sciences 30(4): 1090-1099.

Jacobs JJ, Gilbert JL, Urban RM. 1998. Corrosion of metal orthopaedic implants. Journal of Bone and Joint Surgery 80a: 268-282.

Jellema LM, Latimer B, Walker A. 1993. The rib cage. In The Nariokotome Homo erectus skeleton, Walker AC, Leakey REF (eds.). Harvard University Press: Cambridge; 294-325.

Jurmain R. 2001. Paleoepidemiological patterns of trauma in a prehistoric population from Central California. American Journal of Physical Anthropology 115(1): 13-23. DOI: 10.1002/ajpa.1052

Jurmain R, Bartelink EJ, Leventhal A, Bellifemine V, Nechayev I, Atwood M, DiGiuseppe D. 2009. Paleoepidemiological patterns of interpersonal aggression in a prehistoric central California population from CA-ALA-329. American Journal of Physical Anthropology 139(4): 462-473. DOI: 10.1002/ajpa.21002

Lambert PM. 1997. Patterns of violence in prehistoric hunter-gatherer societies of coastal southern California. In Troubled times: violence and warfare in the Past, Martin DL, Frayer DW (eds.). CRC Press: New York; 77-110.

Linden MA, Manton WI, Stewart RM, Thal ER, Feit H. 1982. Lead poisoning from retained bullets: Pathogenesis, diagnosis, and management. Annals of Surgery 195(3): 305-313.

Lovell NC. 1997. Trauma analysis in paleopathology. Yearbook of Physical Anthropology 40: 139-170. 
Mann RW. 1993. A method for siding and sequencing human ribs. Journal of Forensic Sciences 38: $151-155$.

Machle W. 1940. Lead absorption from bullets lodged in tissues: report of two cases. Journal of the American Medical Association 115(18): 1536-1541. DOI:

10.1001/jama.1940.02810440028006

Meyer C, Brandt G, Haak W, Ganslmeier RA, Meller H, Alt KW. 2009. The Eulau eulogy: Bioarchaeological interpretation of lethal violence in Corded Ware multiple burials from Saxony-Anhalt, Germany. Journal of Anthropological Archaeology 28: 412-423. doi:10.1016/j.jaa.2009.07.002

Owers SK, Pastor RF. 2005. Analysis of quantitative methods for rib seriation using the Spitalfields documented skeletal collection. American Journal of Physical Anthropology 127(2): 210-218. DOI: 10.1002/ajpa.20038

Polos'mak NV, Molodin VI. 1981. Novye nahodki predmetov vooruzheniya rannego zheleznogo veka iz Barabinskoi lesostepi. In Voennoe delo drevnih plemen Sibiri i Central'noi Azii, Hudyakov YuS (ed.). Nauka: Novosibirsk; 74-87.

Reuer E. 1984. Der pfeilspitzenmann von Leopoldau. Archaeologia Austriaca 68: 155-160.

Rokhlin DG. 1965. Diseases of ancient men (bones of the men of various epochs - normal and pathological changed). Nauka: Moscow-Leningrad.

Romanick PC, Smith TK, Kopaniky DR, Oldfield D. 1985. Infection about the spine associated with low-velocity-missile injury to the abdomen. Journal of Bone and Joint Surgery 67a(8): 1195-1201.

Roy M, Somerson JS, Kerr KG, Conroy JL. 2012. Pathophysiology and pathogenesis of osteomyelitis. In Osteomyelitis, Baptista MS (ed.). DOI:10.5772/32171. Available from: http://www.intechopen.com/books/osteomyelitis/pathophysiology-and-pathogenesis

Schutkowski H, Schultz M, Holzgraefe M. 1996. Fatal wounds in a late neolithic double Inhumation - a probable case of meningitis following trauma. International Journal of Osteoarchaeology 6(2): 179-184. DOI: 10.1002/(SICI)1099-1212(199603)6:2<179::AID$\mathrm{OA} 253>3.0 . \mathrm{CO} ; 2-\mathrm{Y}$

Silva AM, Marques R. 2010. An arrowhead injury in a neolithic human axis from the natural cave of Lapa do Bugio (Sesimbra, Portugal). Anthropological Science 118(3): 185-189. DOI: 10.1537/ase.090620

Sjøvold T. 1990. Estimation of stature from long bones utilizing the line of organic correlation. Human evolution 5(5): 431-447.

Stork I, Wahl J. 1988. Eine Doppelbestattung aus Bietigheim, Kreis Ludwigsburg, als Beleg für die Ungarneinfälle des 10. Jahrhunderts. Fundberichte aus Baden-Württemberg 13: 741-775.

Tindel NL, Marcillo AE, Tay BK, Bunge RP, Eismont FJ. 2001. The effect of surgically implanted bullet fragments on the spinal cord in a rabbit model. Journal of Bone and Joint Surgery 83a(6): 884-890.

Vegas JI, Armendaris Á, Etxeberria F, Fernández MS, Herrasti L. 2012. Prehistoric violence in northern Spain: San Juan ante Portam Latinam. In Sticks, stones, and broken bones: Neolithic violence in a European perspective, Schulting RJ, Fibiger L (eds.). Oxford University Press: Oxford; 265-302.

Wilson T. 1901. Arrow wounds. American Anthropologist 3(3): 513-531.

Table 1. Chemical composition of the arrowhead

\begin{tabular}{lllll}
\hline $\begin{array}{l}\text { Sample } \\
\text { no. }\end{array}$ & $\begin{array}{l}\mathrm{Cu} \\
\text { (wt.\%) }\end{array}$ & $\begin{array}{l}\mathrm{Sn} \\
\text { (wt.\%) }\end{array}$ & $\begin{array}{l}\mathrm{Fe} \\
\text { (wt.\%) }\end{array}$ & $\begin{array}{l}\mathrm{Pb} \\
\text { (wt.\%) }\end{array}$ \\
\hline 1 & 80.98 & 18.74 & 0.23 & 0.05 \\
2 & 78.99 & 20.61 & 0.22 & 0.18
\end{tabular}


